\title{
Current practice in paediatric basic life support
}

\author{
Aktualne praktyki w zakresie podstawowych zabiegów resuscytacyjnych u dzieci
}

Jana Heczková ${ }_{\text {, }}$ Alan Bulava ${ }^{2,3,4}$

\begin{abstract}
Institute of Nursing Theory and Practice, First Faculty of Medicine, Charles University, Czech Republic ${ }^{2}$ Department of Cardiology, České Budějovice Hospital, Czech Republic ${ }^{3}$ Faculty of Health and Social Sciences, Universtiy of South Bohemia in České Budějovice, Czech Republic ${ }^{4}$ Faculty of Medicine and Dentistry, Palacky University Olomouc, Czech Republic
\end{abstract}

CORRESPONDING AUTHOR/AUTOR DO KORESPONDENCJI:

Jana Heczková

Charles University

First Faculty of Medicine

Na Bojisti 1771/1, 12000 Prague 2, Czech Republic e-mail: jana.heczkova@lf1.cuni.cz

\section{STRESZCZENIE AKTUALNE PRAKUYKI W ZAKRESIE PODSTAWOWYCH ZABIECÓW RESUSCYTACYJNYCH U DZLEC}

Wstęp. Mimo, że zatrzymanie akcji serca u dzieci występuje znacznie rzadziej niż u dorosłych, stan ten jest wciąż uważany za poważny problem zdrowotny z niską szansą na przeżycie. Podobnie jak w przypadku dorosłych, przepisy dotyczące czasu resuscytacji krążeniowo-oddechowej (RKO) u dzieci są niezwykle istotne. Aktualne wytyczne dotyczące RKO u dzieci zostały opublikowane wraz z wytycznymi dotyczącymi dorosłych w 2015 roku. Podobnie jak w poprzednich latach, są one oparte na porozumieniu Międzynarodowego Komitetu ds. Resuscytacji. Wytyczne poszczególnych członków tej rady mogą się różnić i odzwierciedlać właściwości regionalne, takie jak, różny dostęp do opieki zdrowotnej, metody edukacji, czy gotowość ludzi do pomocy w nagłych przypadkach. Co więcej, stany wymagające RKO u dzieci nie wyróżniają się jedynie częstotliwością występowania, lecz także etiologią czy technikami stosowanymi u różnych grup wiekowych. W związku z tym nacisk kładziony jest na prostotę i wykonalność, jak również na spójność z wytycznymi dotyczącymi dorosłych w celu poprawy zachowywania odpowiedniej kolejności działań w przypadku dzieci.Pielęgniarki mogą być pierwszymi ratownikami nie tylko w placówkach opieki zdrowotnej. Lepsze zrozumienie wytycznych RKO może przyczynić się do polepszenia ich umiejętności wykrywania stanów wymagających resuscytacji krążeniowo-oddechowej oraz do zapewniania skutecznej pomocy w nagłych przypadkach.

Cel pracy. Celem badania jest porównanie różnych podejść do RKO u dzieci, zwłaszcza do podstawowych zabiegów resuscytacyjnych, stosowanych w aktualnych wytycznych różnych członków Międzynarodowego Komitetu ds. Resuscytacji.

Wyniki i wnioski. Ogólny algorytm do RKO u dorosłych może być stosowany w przypadku ofiar w różnym wieku, lecz w przypadku dzieci, nieco inne podejście może dać dużo bardziej zadawalające efekty.

Słowa kluczowe: wytyczne RKO, oddychanie ratownicze, uciski klatki piersiowej, automatyczny defibrylator zewnętrzny

\section{ABSTRACT CURRENT PRACTICE IN PAEDIATRIC BASIC LIFE SUPPORT}

Introduction. Although the incidence of cardiac arrest in children is much lower than in adults, the condition is still considered a major health problem with a very low chance for survival. As in adults, the timely provision of cardiopulmonary resuscitation (CPR) in children is crucial. Current guidelines for CPR in children were published along with the guidelines for CPR in adults in 2015. As in previous years, they are based on consensus provided by International Liaison Committee on Resuscitation (ILCOR). Guidelines of particular ILCOR member councils may vary and reflect regional characteristic such as different access to health care, education methods or willingness of population to provide emergency assistance. Moreover, the conditions requiring CPR in children are characterized not only by different incidence, but also by aetiology or techniques used for different age groups. Therefore, emphasis is put on simplicity and feasibility as well as on consistency with adult guidelines to improve retention of the paediatric sequences. Nurses may be first rescuers not only in health care facilities. Better understanding of CPR guidelines might help them to improve their ability to detect conditions requiring CRP and also initiate and provide effective emergency care.

Aim. The aim of this study is to compare different approaches to paediatric (PR, in particular to basic life support (BLS), used in current guidelines of different ILCOR member councils.

Results and conclusions. General algorithm for adult CPR may be followed for victims of all age, but in case of children, slightly different approach might have much more favourable outcome.

Key words: $\quad$ CPR guidelines, rescue breathing, chest compressions, automatic external defibrillator (AED) 


\section{INTRODUCTION}

Cardiac arrest is considered a major health problem. Its incidence outside the hospital exceeds half of million people each year $[1,2]$, although a unified system of reporting is not available yet [3]. Early recognition of this event and the initiation of cardiopulmonary resuscitation (CPR) are two vital steps with significant impact on eventual outcome $[4,5]$. The current guidelines for CPR were published in October 2015. As in previous years, they are based on consensus and treatment recommendation of the International Liaison Committee on Resuscitation (ILCOR) formed by representatives of member councils (table 1). Consensual statement in 2015 was the result of previous cooperation of experts from 39 countries. ILCOR members councils then created own guidelines where not only international consensus and recommendation but also the regional specifics including economic or infrastructural differences were reflected $[4,6,7]$.

\section{AIM}

The aim of this study is to highlight different approaches to implementation and regional adaptation of scientific results to help understand current guidelines for paediatric CPR, in particular paediatric basic life support (BLS).

\begin{tabular}{|c|c|}
\hline $\begin{array}{c}\text { International Liaison Committee on } \\
\text { Resuscitation (ILCOR) }\end{array}$ & www.ilcor.org \\
\hline $\begin{array}{l}\text { America } \\
\text { The American Heart Association (AHA) } \\
\text { The Heart and Stroke Foundation of Canada (HSFC) } \\
\text { The Inter-American Heart Foundation (IAHF) }\end{array}$ & $\begin{array}{l}\text { www.heart.org } \\
\text { www.heartandstroke.com } \\
\text { www.interamericanheart.org }\end{array}$ \\
\hline $\begin{array}{l}\text { Europe } \\
\text { The European Resuscitation Council (ERC) }\end{array}$ & www.erc.edu \\
\hline $\begin{array}{l}\text { Asia } \\
\text { The Resuscitation Council of Asia (RCA) }\end{array}$ & www.resuscitationcouncil.asia \\
\hline $\begin{array}{l}\text { Africa } \\
\text { The Resuscitation Council of Southern Africa (RCSA) }\end{array}$ & www.resus.co.za \\
\hline $\begin{array}{l}\text { Australia and New Zealand } \\
\text { The Australian and New Zealand Committee } \\
\text { on Resuscitation (ANZCOR) }\end{array}$ & $\begin{array}{l}\text { www.resus.org.au } \\
\text { www.nzrc.org }\end{array}$ \\
\hline
\end{tabular}

The European Resuscitation Council (ERC) is the authority responsible for CPR guidelines for European region. They take into account not only scientific evidence but also three main characteristics of cardiac arrest in children. They are as follows: 1) incidence of serious diseases in children is much lower than in adults, 2) disease and pathophysiological response may occur differently in children than in adults, 3) emergency assistance is initially provided mainly by rescuers without specialized knowledge in the field of paediatrics. For this reason simplicity and feasibility were stressed in order to produce guidelines applicable easily into practice $[4,6,8]$.

Procedures and techniques used for CPR in children may vary according to age and body constitution of the victim, therefore specific terms are used to describe age groups for the purpose of CPR. The term infant describes a child under 1 year of age but does not include newborn baby at the delivery room. The term child means age group from 1 year to the onset of puberty and the term adolescent group from the onset of puberty and older. Paediatric CPR is applicable for infants and children. There are specific guidelines for neonatal CPR at the delivery room and guidelines for adult CPR are recommended for adolescent victim (table 2). The decision of age group is based on rescuer estimation. Little or no harm is expected in case of misjudgement, as there is not strict age line in cardiac arrest pattern [8-10].

\section{Tab. 2. Guidelines for CPR according to age groups.}

\begin{tabular}{|l|l|}
\hline \multicolumn{1}{|c|}{ Age group } & \multicolumn{1}{c|}{ Guidelines for CPR } \\
\hline Newborn (at the delivery room) & guidelines for neonatal CPR \\
\hline Infant (under 1 year of age) & guidelines for paediatric CPR \\
\hline Child (from 1 year to the onset of puberty) & guidelines for paediatric CPR \\
\hline Adolescent (from the onset of puberty and older) & guidelines for adult CRP \\
\hline
\end{tabular}

In rescuers without specific knowledge of paediatric $\mathrm{CPR}, \mathrm{ERC}$ recommends using procedures identical to CPR in adults [4], including CPR without rescue breathing, which when compared to "doing nothing” has much more positive outcome [4, 7, 10-15]. However, asphyxial cardiac arrest is more common in children in comparison to adult victims and CPR with rescue breathing may have greater positive impact on the results $[4,6,8,10]$. ERC recommends that non-specialists who have responsibility for children should be taught paediatric sequences if they wish so $[4,6,8]$. On the contrary AHA created specific BLS algorithm for healthcare providers [10] and ANZCOR provides the same guidelines for BLS in children as in adults [16] and only guidelines for advanced life support differ [17].

\section{Initiation of CPR}

The modified sequences DR ABC [16] will be used in further text to structure procedures on the scene of emergency (table 3 ).

\section{(D) Danger}

The first step in providing emergency care, as in previous guidelines, is to evaluate whether there is no more immediate danger and to ensure "safe” environment for all involved $[4,8]$. In the broader context, the protection of the rescuer against the transmission of infectious diseases can be included but this risk is considered as very low $[7,10,16,18,19]$.

\section{(R) Response}

Primary assessment starts with basic evaluation of the level of consciousness and involves checking response to verbal and tactile stimulation. If the child responds (by movement, crying, verbally), it is clear that immediate CRP is not needed. The condition needs to be assessed, emergency services called and appropriate help provided if necessary. In order not to cause more harm, the position 
Tab. 3. Initiation of (PR according to ERC (modified according to ERC).

\begin{tabular}{|c|c|}
\hline Child under 1 year & Child over 1 year \\
\hline $\begin{array}{l}\text { (D) Check and ensure safety } \\
\text { (R) Check for Response } \\
\text { (A) Open the airways } \\
\text { - head tilt, chin lift } \\
\text { - jaw thrust } \\
\text { (B) } 5 \text { rescue breaths } \\
\text { - mouth to mouth and nose } \\
\text { (C) Chest compression } \\
\text { - two fingers technique } \\
\text { - encircling technique } \\
\text { CPR } 15: 2\end{array}$ & $\begin{array}{l}\text { (D) Check and ensure safety } \\
\text { (R) Check for Response } \\
\text { (A) Open the airways } \\
\text { - head tilt, chin lift } \\
\text { - jaw thrust } \\
\text { (B) } 5 \text { rescue breaths } \\
\text { - mouth to mouth } \\
\text { - mouth to nose } \\
\text { (C) Chest compression } \\
\text { - One hand technique } \\
\text { - Two hands technique } \\
\\
\text { CPR } 15: 2\end{array}$ \\
\hline
\end{tabular}

of the victim should not be changed unless there is any reason do so, but it is important to regularly recheck condition till handover for professional care $[4,8,10,20]$.

However, if a child does not respond to stimulation, it should be carefully turned onto the back to assess the presence of signs of life. At the same time, it is recommended to try to obtain someone else to help by shouting for help $[4,8]$.

\section{(A) Airway}

The basic procedure for opening the airways is head tilt and chin lift. Rescuer needs to place one hand on the child's forehead and tilt the head slightly backwards while fingers of the rescuer's other hand gently pulling the child's chin up. For children under 1 year, it is necessary to pay attention to the soft tissues under the chin, as its excessive compression can lead to airway obstruction. Simultaneously, the head should not to be overextended but rather kept in neutral position. To simplify maintaining the correct position of the head, pad placed under the child's upper torso can be used. In case of suspected cervical spine injury, it is possible to do jaw thrust. However, it is necessary to remember that the opening of the airway is priority in the unconscious victim. If the jaws thrust cannot open airway sufficiently, the head tilt needs to be added in slow steps. Any visible obstruction from the victim's mouth can be removed using rescuer's fingers but it is not recommended to do any blind sweep $[4,8,10,21]$.

The subsequent check-up for presence of the normal breathing should not exceed 10 seconds. To assess breathing, it is necessary to keep airways open and at the same time check for the presence of normal breathing by looking at the chest, listening to any breath sounds, and feeling flow of the exhaled air on rescuer cheek placed above the victim's face $[4,8]$.

Gasping (infrequent, irregular, abnormal breathing) can persist after cardiac arrest for a few minutes. It is essential not to mistaken gasping with normal breathing.
If the child is not breathing, not breathing normally, or rescuer is not sure if breathing is normal, it is necessary to initiate CPR $[4,8,10,16]$. It is also emphasized that CPR should be started for presumed cardiac arrest without concerns, as there is only negligible risk for victim inaccurately assessed and received CPR when not necessary [16].

However, first sequences of CPR differ if compared ERC and AHA guidelines. Currently it is not clear if the initiation of CPR with rescue breathing or chest compressions has any effect on the time of recovery of spontaneous circulation or improved survival in children [4, 6-8, $10,22,23]$. Due to the fact that CPR starts with rescue breaths, which are emphasized by the difference in aetiology of cardiac arrest in children [6,24], is well establish in Europe, and it has not been found sufficient evidence for a change, ERC decided to continue with already well recognized sequences $[4,15]$. In contrast, the AHA guidelines highlight the benefit of a single procedure in initiation of CPR in all age groups, children as well as adults $[7,10]$. The same approach characterizes ANZCOR guidelines $[16,21]$.

\section{(B) Breathing}

As highlighted above, ERC recommends to start CPR with five rescue breaths $[4,8]$. The most commonly used technique in children over 1 year as well as in adult is mouth-to-mouth breathing. Rescuer will take a breath, keep child's head tilted, pinch soft part of the child's nose with own index finger and thumb, cover the child's mouth with own lips so that good seal is achieved, blow steadily for 1 second and at the end will allow exhalation. Procedure will be repeated so that 5 rescue breaths would be given. Mouth-to-mouth-and-nose breathing is preferred in case the victim is younger than 1 year of age. The rescuer then cover the infant's mouth and nose. If it is not possible to achieve good seal, mouth-to-mouth or mouth-to-nose breathing can be used as well. If mouth-to-nose breathing is used, it is necessary to keep victim's lips closed to prevent air escape $[4,8,10]$. When appropriate, it is also possible to use mouth-to-tracheostomy breathing [19].

The duration of one breath, both initial and subsequent during CPR, is newly recommended in accordance with the duration of the rescue breaths in adults and should last about 1 second. If the chest does not rise during attempt for rescue breath, it may be necessary to reposition the victim's head to achieve airway patency $[4,8,10]$. Excessive ventilation should be avoided as possible risk include increased intrathoracic pressure, decreased cerebral and coronary perfusion as well as gastric inflation leading to regurgitation and aspiration of stomach content $[8,10]$.

While rescue breaths are provided, the circulation is evaluated by assessing the presence of the signs of life (normal breathing, movement, coughing). Checking pulse is not necessary and it is stressed as unreliable sign. It is mentioned in AHA algorithm for professional rescuers, but it is required to be done simultaneously with assessing presence of normal breathing and it is emphasized that decision must be done within 10 seconds $[4,8,10]$. If the rescuer is confident that signs of life are present, 
he/she should continue with rescue breathing if necessary in the rate of about 12 to 20 breaths/minute till victim is breathing sufficiently $[4,8]$. AHA guidelines for professional rescuers recommend reassessment of pulse every 2 minutes and if the pulse is less than $60 /$ minute and the signs of poor perfusion are present in spite of rescue breathing, chest compressions should be started [10]. The absence of signs of life after the initial rescue breaths should be considered sign of cardiac arrest and the reason to carry on with chest compressions. It is also emphasized that agonal gasping is sign of cardiac arrest and requires immediate response $[4,8,10]$.

\section{(C) Circulation}

Chest compressions should be performed in the lower half of the breastbone at the rate of 100-120/minute. The techniques vary depending on the age of the victim. One or two hands technique can be used in children older than one year of age. The rescuer should be kneeling by the side of the victim and place the heel of his/her hand on the child's breastbone one finger's width above the ribs connection. In case of one hand technique the rescuer uses his/her hand to keep the child's head slightly tilted. For two hands technique the rescuer puts another hand over first one and interlock fingers. The arms are kept straight and fingertips lifted to avoid pressure over child's ribs during compressions $[4,8,25]$.

When the victim is infant and there is lone rescuer, two fingers technique is used. The rescuer is by the side of the victim and compresses breastbone using tips of his/ her index and middle fingers. The encircling technique is recommended for two or more rescuers. One rescuer places both thumbs side by side on the lower half of breastbone so that tips are pointing towards the victim's head $[4,8,10,25]$. AHA additionally specified that chest compressions site is just below the imaginary line connecting the nipples $[7,10]$. The rescuer's fingers are spread around the infant's chest and tips support the back $[4,8,10]$. This technique is preferred as very likely generate greater force of compressions leading to appropriate depth of chest compressions as well as higher systolic and diastolic pressure, but another rescuer needs to be present to provide rescue breathing [10].

The optimal depth of chest compressions is at least $1 / 3$ of anterior-posterior chest diameter or at least $5 \mathrm{~cm}$ in child older than 1 year and at least $4 \mathrm{~cm}$ in infant $[4,6$, $8,10,15,25]$. The difference between these two approaches for estimation of chest compressions depth does not appear to be statistically significant [15], but the importance of sufficient depth of chest compressions is emphasized as it appears to have a positive impact on the time to return of spontaneous circulation and neurologic outcome $[9,15,26,27]$.

Rate of the chest compressions under an assumption of sufficient depth should be about 100-120/minute. The recommendation was adopted in absence of paediatric data from guidelines for adult victims to simplify education and maximize retention [4, 7-10, 25]. The use of feedback devices allowing optimization of the rate and the depth appears as reasonable $[6,9,10]$.
The CPR should continue without interruption until signs of life are seen, emergency service takes CPR over, or the rescuer become exhausted. However, the optimal ratio of chest compressions and rescue breathing in children is unknown and particular guidelines differ again. ERC recommends to carry out CPR in the ratio of 15 chest compressions : 2 rescue breaths $[4,8]$. Conversely AHA recommends this ratio only if more professional rescuers are present [10]. Uniform ratio of 30:2 for all victims, regardless of age, is recommended by AHA in case of lay or only one professional rescuer $[7,10]$ as well as by ANZCOR [25].

The effort to minimize interruption of the chest compressions (e.g. in order to allow the rescue breaths) is considered as essential $[4,8,10,16]$; ERC and AHA guidelines require not to exceed 10 seconds $[4,8,10]$. Similarly the chest should be sufficiently released after each compression, otherwise there is a risk of increasing intrathoracic pressure, decreased venous return and decreased coronary as well as cerebral perfusion [10]. The rescuer rotates in providing chest compressions after 2 minutes if more than 1 rescuer is present to prevent fatigue and deterioration in chest compressions quality $[10,25]$.

\section{Calling for professional help}

Activating the emergency system (in a medical facility calling for the emergency response team) is an important step in providing emergency care. The number 112 is emergency phone number available in the European Union countries. If more than one rescuer is present, one rescuer calls for help immediately when it is clear that the condition will require CPR $[4,10]$. In case of lone rescuer ERC recommends to provide CPR for about 1 minute or 5 cycles and subsequently going for assistance [8]. AHA guidelines recommend to call for help immediately, if mobile phone preferably with speaker is available, if it is not available, then initiate and provide CPR for 2 minutes before leaving the victim to activate emergency response system [10].

The CPR is continued after rescuer's return. If the victim is infant, it may be possible to carry the victim to minimize interruption in CPR. However, if rescuer witnessed sudden collapse, emergency services should be activated immediately, even before CPR is started, as in case of emergency in adult victim. It is unlikely situation, but if primary cardiac arrest is suspected, urgent defibrillation may be needed $[8,10]$.

\section{Automatic external defibrillator}

As in the adult victims, it is possible to use an automatic external defibrillator (AED) if available. The incidence of shockable rhythm increases with the child's age. The use of paediatric paddles as well as paediatric mode if available, is recommended for child from 1 to 8 years old $[8,10]$. As in adult victims, the use of AED should not delay initiation of CPR, but the paddles should be attached immediately after AED is available in anterior-lateral position (one electrode paddle below right clavicle and the other in the left axilla). If paediatric size is not available and paddles are too large, they should be placed in anterior-posterior 
position (one on back below left scapula and another one on the front left to the breastbone). If more than one rescuer is on the scene, paddles are attached during continuing CPR. Consequently, the rescuer needs to ensure nobody is touching the victim to allow rhythm analysis and to act as directed by voice or visual prompts. If shock is indicated, half automatic AEDs will require the rescuer to deliver it by pushing shock button. It is necessary that nobody is in direct contact with the victim during shock delivery and CPR is resumed immediately after. Chest compressions should be interrupted every 2 minutes to allow cardiac rhythm assessment and shock delivery if necessary $[4,10,28]$.

\section{Recovery position}

The unconscious victim who is breathing normally should be placed into recovery position. The purpose of this measure is to maintain airways and prevent fluids (vomit, saliva, etc.) to be aspirated. A few modifications of recovery position are known. The main principle is placing victim in a stable position on side that allow breathing and free drainage of fluids from mouth. The position needs as well to allow turning the victim onto his/her back easily in case it is necessary to reassume CPR $[8,18]$.

\section{CONCLUSION}

Conditions requiring CPR in children are less common than in adults but require similar immediate response in order to safe victim's life. Although general algorithm used for adult CPR can be followed, modified approach can lead to more positive outcome. The guidelines for CPR of particular resuscitation councils may vary but the main aim is to achieve the best possible regional adaptation and implementation into practice. Good understanding of CPR algorithms may help rescuers to initiate and provide effective emergency care.

\section{REFERENCES}

1. Berdowski J, Berg RA, Tijssen JG, Koster RW. Global incidences of out-of-hospital cardiac arrest and survival rates: Systematic review of 67 prospective studies. Resuscitation, 2010; 81(11): 1479-1487.

2. Grasner JT, Lefering R, Koster RW, et al. EuReCa ONE-27 Nations, ONE Europe, ONE Registry: A prospective one month analysis of out-of-hospital cardiac arrest outcomes in 27 countries in Europe. Resuscitation. 2016;105: 188-195.

3. Nishiyama C, Brown SP, May S, et al. Apples to apples or apples to oranges? International variation in reporting of process and outcome of care for out-ofhospital cardiac arrest. Resuscitation. 2014; 85(11): 1599-1609.

4. Monsieurs KG, Nolan JP, Bossaert LL, et al. European Resuscitation Council Guidelines for Resuscitation 2015: Section 1. Executive summary. Resuscitation. 2015; 95: 1-80.

5. Nolan JP, Soar J, Zideman DA, et al. European Resuscitation Council Guidelines for Resuscitation 2010 Section 1. Executive summary. Resuscitation. 2010; 81(10): 1219-1276.

6. Nolan JP, Hazinski MF, Aickin R, et al. Part 1: Executive summary. 2015 International Consensus on Cardiopulmonary Resuscitation and Emergency Cardiovascular Care Science with Treatment Recommendation. Resuscitation. 2015; 95: e1-e31.

7. AHA. Highlights of the 2015 American Heart Association Guidelines. Update for CPR and ECC. [online]. 2015, Available from: https://eccguidelines.heart.org/wpcontent/uploads/2015/10/2015-AHA-Guidelines-Highlights-English.pdf.

8. Maconochie IK, Bingham R, Eich C, et al. European Resuscitation Council Guidelines for Resuscitation 2015 Section 6. Paediatric life support. Resuscitation. 2015; 95: 223-248.

9. Atkins DL, Berger S, Duff JP, et al. Part 11: Pediatric Basic Life Support and Cardiopulmonary Resuscitation Quality: 2015 American Heart Association Guidelines Update for Cardiopulmonary Resuscitation and Emergency Cardiovascular Care. Circulation. 2015; 132(18 Suppl 2): S519-525.
10. AHA. Part 11: Pediatric Basic Life Support and Cardiopulmonary Resuscitation Quality. [online]. 2015, Available from: https://eccguidelines.heart.org/index. $\mathrm{php} /$ circulation/cpr-ecc-guidelines-2/part-11-pediatric-basic-life-support-andcardiopulmonary-resuscitation-quality/.

11. Goto Y, Maeda T, Goto Y. Impact of dispatcher-assisted bystander cardiopulmonary resuscitation on neurological outcomes in children with out-of-hospital cardiac arrests: a prospective, nationwide, population-based cohort study. Journal of the American Heart Association. 2014; 3(3): e000499.

12. Iwami T, Kitamura T, Kawamura T, et al. Chest compression-only cardiopulmonary resuscitation for out-of-hospital cardiac arrest with public-access defibrillation: a nationwide cohort study. Circulation. 2012; 126(24): 2844-2851.

13. Iwami T, Kitamura T, Kiyohara K, Kawamura T. Dissemination of Chest CompressionOnly Cardiopulmonary Resuscitation and Survival After Out-of-Hospital Cardiac Arrest. Circulation. 2015; 132(5): 415-422.

14. Kitamura T, Iwami T, Kawamura T, et al. Conventional and chest-compression-only cardiopulmonary resuscitation by bystanders for children who have out-of-hospital cardiac arrests: a prospective, nationwide, population-based cohort study. The Lancet. 2010; 375(9723): 1347-1354.

15. Maconochie IK, de Caen AR, Aickin R, et al. Part 6: Pediatric basic life support and pediatric advanced life support. 2015 International Consensus on Cardiopulmonary Resuscitation and Emergency Cardiovascular Care Science with Treatment Recommendations. Resuscitation. 2015; 95: e147-e168.

16. ANZCOR. ANZCOR Guideline 8 - Cardiopulmonary Resuscitation. [online]. 2016 Available from: https://resus.org.au/guidelines/.

17. ANZCOR. All Paediatric Advanced Life Support guidelines. [online]. 2016, Available from: http://www.nzrc.org.nz/assets/Uploads/Guidelines/Paed-ALS/All-Paed-ALSguidelines-Jan-2016.pdf.

18. ANZCOR. ANZCOR Guideline 2 - Managing an Emergency. [online]. 2016, Available from: https://resus.org.au/guidelines/

19. ANZCOR. ANZCOR Guideline 5 - Breathing. [online]. 2016, Available from: https:// resus.org.au/guidelines/.

20. ANZCOR. ANZCOR Guideline 3 - Recognition and First Aid Management of the Unconscious Person. [online]. 2016, Available from: https://resus.org.au/guidelines/.

21. ANZCOR. ANZCOR Guideline 4 - Airway. [online]. 2016, Available from: https://resus. org.au/guidelines/.

22. Lubrano $R$, Cecchetti $C$, Bellelli $E$, et al. Comparison of times of intervention during pediatric $C P R$ maneuvers using $A B C$ and $C A B$ sequences: $A$ randomized trial. Resuscitation. 2012: 83(12): 1473-1477.

23. Marsch $S$, Tschan $F$, Semmer NK, et al. $A B C$ versus $C A B$ for cardiopulmonary resuscitation: a prospective, randomized simulator-based trial. Swiss Medical Weekly. 2013; 143: w13856.

24. Deasy C, Bernard SA, Cameron P, et al. Epidemiology of paediatric out-of-hospital cardiac arrest in Melbourne, Australia. Resuscitation. 2010; 81(9): 1095-1100.

25. ANZCOR. ANZCOR Guideline 6 - Compressions. [online]. 2016, Available from: https://resus.org.au/guidelines/.

26. Sutton RM, French B, Niles DE, et al. 2010 American Heart Association recommended compression depths during pediatric in-hospital resuscitations are associated with survival. Resuscitation. 2014; 85(9): 1179-1184.

27. Maher KO, Berg RA, Lindsey CW, et al. Depth of sternal compression and intra-arteria blood pressure during (PR in infants following cardiac surgery. Resuscitation. 2009; 80(6): 662-664.

28. ANZCOR. ANZCOR Guideline 7 - Automated External Defibrillation in Basic Life Support. [online]. 2016, Available from: https://resus.org.au/guidelines/.

Manuscript received: 10.02.2017

Manuscript accepted: 18.04.2017

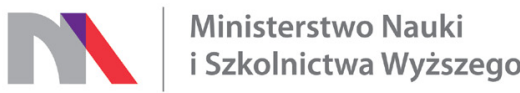

„Konsultacje z zagranicznymi naukowcami i wprowadzenie dwujęzycznych (j. polski/angielski) treści do czasopisma Pielegniarstwo XXI wieku" finansowane w ramach umowy 547/P-DUN/2016 ze środków Ministra Nauki i Szkolnictwa Wyższego przeznaczonych na działalność upowszechniającą naukę. 